\title{
KEPRIBADIAN SULIT DAN KEGAGALAN KULIAH MAHASISWA
}

\author{
Tukina \\ Jurusan Marketing Communication, Fakultas Ekonomi dan Komunikasi, BINUS University \\ Jln. K.H. Syahdan No. 9, Palmerah, Jakarta Barat 11480
}

\begin{abstract}
Student life in university has many dynamics. One of the important and basic problems that could threat successful learning in the university is difficult personality of the student. The article discusses many students failed in university because of having difficult personality. Therefore, handling difficult personality among students must be done as soon as possible. Based on analysis of literature study, efforts in handling difficult personality must be done through the exact education purpose. This is to be thought many parts, including academic community in the university to create students having knowledge and technology and also good characteristic.
\end{abstract}

Keywords: university, students, difficult personality

\begin{abstract}
ABSTRAK
Kehidupan mahasiswa di universitas mengalami banyak dinamika. Salah satu kendala krusial dan mendasar yang dapat mengancam keberhasilan belajar di universitas adalah masalah kepribadian sulit. Artikel membahas tentang banyak mahasiswa gagal belajar di universitas karena mengalami kepribadian yang sulit. Oleh karena itu, penanganan kepribadian sulit dikalangan mahasiswa perlu segera dilakukan. Berdasarkan analisis dari studi pustaka, upaya mengatasi kepribadian sulit tersebut perlu dilakukan dengan mengedepankan dan berdasarkan tujuan pendidikan yang tepat. Hal itu perlu dipikirkan semua pihak terutama civitas akademika di universitas untuk menciptakan mahasiswa yang di samping memiliki dan menguasai ilmu pengetahuan dan teknologi serta memiliki berkepribadian (berkarakter) yang baik.
\end{abstract}

Kata kunci: universitas, mahasiswa, masalah kepribadian 


\section{PENDAHULUAN}

Pendidikan tinggi (universitas) merupakan wahana bagi mahasiswa membekali dirinya dengan ilmu pengetahuan, teknologi, dan aklaq yang mulya (berkarakter yang baik) serta memiliki nilai-nilai keimanan dan ketaqwaan kepada Tuhan Yang Maha Esa. Penguasaan hal tersebut diatas oleh mahasiswa merupakan hal yang penting dan mendasar sehingga mahasiswa diharapkan dapat mengambil peran menentukan dan konstruktif dalam kehidupan nyata. Maksud kuliah di Universitas seringkali kurang dimengerti dan dipahami secara optimal sehingga sebagian mahasiswa mengalami kegagalan studi bahkan banyak di antaranya (tentunya lebih dari satu orang) tidak sampai lulus.

Untuk istilah kegagalan studi sebenarnya lebih luas, bisa saja mahasiswa lulus Universitas tetapi kualitas mahasiswa sebenarnya dibawa standar. Di bawah standar sendiri bisa diartikan dari kualitas yang sangat sangat rendah, sangat rendah sampai rendah. Perlu dicatat kegagalan studi bisa berarti si mahasiswa lulus namun tingkat kelulusan asal-asalan. Sebutan umum untuk mahasiswa yang tidak lulus adalah doup out (DO). Tentunya kalau ditelisik dan diteliti sebab atau alasan ketidaklulusan mahasiswa di universitas tentunya disebabkan oleh berbagai faktor.

Studi terhadap kegagalan mahasiswa di perguruan tinggi sangat minim dilakukan. Kenyataan bahwa ada sebagian dari mahasiswa di universitas yang asal lulus dan sebagian lagi tidak mampu memperoleh gelar kesarjanaan (gagal kuliah) atau DO sebenarnya ada didepan mata namun pencarian solusi belum dilakukan secara memadai. Bagi yang gagal kuliah terdapat pertanyaan menarik dan perlu direnungkan yaitu apakah pendidikan ditingkat universitas yang ditempuh mahasiswa selama 4 sampai sekitar 7 tahun membuahkan hasil perubahan pada diri mahasiswa (menyangkut sikap, perilaku dan pengetahuan) secara mendasar. Bila tidak maka mahasiswa dapat dikatakan kurang berhasil bahkan gagal kuliah di Universitas.

Secara umum terdapat pandangan bahwa penyebab kegagalan mahasiswa kuliah di universitas adalah faktor keuangan (finansial). Pendapat tersebut sebenarnya tidak salah namun belum terbukti kebenarannya apalagi sebagian dari yang gagal tersebut terkadang berperilaku dan berpenampilan jauh dari kesan miskin, betapa tidak ke kampus membawa mobil, motor yang mahal dan ponsel pun bukan ponsel murahan. Bahkan kalau diteliti, kebanyakan mereka bukan dari keluarga yang tidak mampu. Lalu pertanyaan berikutnya, apa sebenarnya yang menyebabkan kegagalan mahasiswa kuliah di universitas selain faktor finansial tersebut?

Pertanyaan yang berkaitan dengan apa yang sebenarnya yang merupakan faktor yang turut andil dalam kegagalan mahasiswa kuliah di universitas perlu dikaji dengan fakta lain yang dapat dikatakan terlibat. Fakta bahwa sikap mental (karakter) mahasiswa yang buruk belum banyak diungkap terutama yang berkaitan dengan keberhasilan atau kegagalan mahasiswa kuliah di universitas. Kenyataannya ada sebagian mahasiswa yang tidak mau mengerjakan tugas, jarang masuk atau bahkan tidak masuk sama sekali, berani melawan dosen, pimpinan jurusan dan universitas, tidak sopan, kalau bicara menyakitkan dan meremehkan orang lain, selalu mencari alasan untuk tindakan atau perilaku yang tidak benar agar dapat dibenarkan, suka tidak jujur dan lain sebaginya.

Untuk perilaku dan sikap yang tidak jujur dikalangan mahasiswa saat ini perlu menjadi penekanan atau perhatian serius semua pihak terutama dikalangan pendidikan tinggi. Sikap perilaku sebagian anggota masyarakat yang mempertontonkan ketidakjujuran seringkali juga dijumpai dikalangan mahasiswa. Hal ini terasa penting dan mendasar karena mahasiswa adalah masa depan. Dikuatirkan kalau ketidakjujuran ini meluas maka di negara Indonesia ini nantinya merebag (menjamur) penyakit korupsi, kolusi dan nepotisme (KKN) yang semakin menggila merusak sendisendi dasar kehidupan bernegara dan sulit dibrantas apalagi kalau tidak disadari dikalangan Universitas. Sikap dan perilaku serta tindakan seperti diatas dapat diwakili dengan kata-kata berkarakter yang buruk bahkan sebagian darinya mengalami kepribadian yang sulit (difficulty 
personality). Untuk hal yang berkaitan dengan diffiulty personality sebenarnya merupakan bagian dari kharakter yang buruk (jelek).

Bila pendidikan tinggi tidak mengantisipasi dan meminimalisir pribadi yang sulit ini maka dalam kehidupan bangsa Indonesia akan semakin buruk pula. Hal ini perlu disadari karena pembentukan sumber daya manusia dalam era ini tempat yang tepat adalah universitas (perguruan tinggi). Terlebih-lebih pada saat ini, ada indikator yang kuat dimasyarakat terjadi kerusakan mental sebagian warga bangsa Indonesia. Rusaknya mental sebagian warga bangsa Indonesia ditandai dengan adanya perubahan sikap dan perilaku sebagian masyarakat Indonesia yang tidak lagi mengedepankan kejujuran dan diperparah dengan sikap dan perilaku yang lebih muda terpancing (emosional) dalam berbagai sisi kehidupan serta miskin kepedulian terhadap sesama. Hal tersebut bila dibiarkan mengakibatkan hilangnya hati nurani.

Dahulu, masyarakat Indonesia dikenal sangat toleran, ramah, santun dan gemar bergotong royong, namun kini masyarakat cenderung mudah marah, main hakim sendiri dan terpancing melakukan kekerasan (teror). Hal tersebut menunjukan kesehatan mental sebagian masyarakat semakin rapuh. Pemicu banyak hal dari rasa tidak nyaman, cemas, sampai depresi sebagian anggota masyarakat karena kemiskinan, kebodohan, ketidakadilan dalam berbagai bidang serta ketidakpastian masa depan. Ketidakpastian masa depan dapat memicu peningkatan kriminalitas, kekerasan, kenakalan remaja/mahasiswa, bahkan benih-benih korupsi. Hal tersebut bersumber pada krisis multidimensional, frustasi, konflik, dan sikap saling curiga. Sebagian masyarakat menjadi paranoid, terpancing melakukan kekerasan massal dan histeria massal. Akibat ketidakpastian lain lahirlah hukum rimba, hukum tidak lagi berpihak pada yang benar dan adil. Kondisi terakhir tersebut menyebabkan sebagian masyarakat memilih jalur lain sebagai bentuk keadilan rakyat.

Untuk mengantisipasi semakin rusaknya mental bangsa tersebut maka Universitas sebagai tempat membentuk sikap mental atau kharakter berbangsa yang handal perlu menciptakan situasi dan kondisi yang kondusif agar mahasiswanya dapat lulus serta berupaya meminimalisir angka tidak selesai di tengah jalan/drop out (DO). Walaupun ini terkesan sulit dan merupakan upaya yang idealis namun bukan berarti tidak dapat diwujudkan. Bila tidak diantisipasi maka mahasiswa yang tidak lulus tersebut bisa menjadi masalah bagi keluarga, masyarakat dan terlebih-lebih pada bangsa Indonesia di kemudian hari. Di samping itu tentunya juga berkaitan dengan nama baik universitas itu sendiri yang dipertaruhkan di tengah-tengah masyarakat Indonesia dan global.

\section{Pendidikan Tinggi (Universitas) dalam Lingkup Pendidikan Nasional}

Pada dasarnya manusia membutuhkan pendidikan dalam kehidupannya. Hanya saja banyak diantara manusia Indonesia tersebut kesulitan untuk mendapatkan pendidikan yang diharapkan. Dalam konstitusi negara Indonesia, UUD 1945 alinea 4 ditegaskan yang merupakan tujuan/cita-cita bangsa Indonesia salah satunya adalah mencerdaskan kehidupan bangsa. Dalam upaya mencerdaskan kehidupan bangsa tersebut maka peran Pendidikan Tinggi (Universitas) menjadi sesuatu yang dapat diandalkan.

Dalam Undang-Undang Negara Republik Indonesia Tahun 1945 Pasal 31 ayat (1) menyebutkan bahwa setiap warga negara berhak mendapat pendidikan, dan ayat (3) menegaskan bahwa Pemerintah mengusahakan dan menyelenggarakan satu sistem pendidikan nasional yang meningkatkan keimanan dan ketakwaan serta akhlak mulia dalam rangka mencerdaskan kehidupan bangsa tersebut. Untuk itu, seluruh komponen bangsa termasuk masyarakat wajib mencerdaskan kehidupan bangsa yang merupakan salah satu tujuan negara Indonesia.

Dalam hubungannya dengan pendidikan, prinsip-prinsip demokrasi, desentralisasi (otonomi), keadilan, dan menjunjung tinggi hak asasi manusia akan memberikan dampak yang mendasar pada kandungan, proses, dan manajemen universitas. Selain itu, perkembangan ilmu pengetahuan dan 
teknologi berkembang pesat dan memunculkan tuntutan baru dalam segala aspek kehidupan, termasuk dalam hal manajemen universitas dan otonomi penyelenggaraan universitas. Pembaharuan sistem pendidikan juga meliputi penghapusan diskriminasi antara pendidikan yang dikelola pemerintah dan masyarakat, serta pembedaan antara pendidikan keagamaan dan pendidikan umum.

Pembaharuan sistem pendidikan nasional dilakukan untuk memperbaharui visi, misi, dan strategi pembangunan pendidikan nasional. Pendidikan nasional mempunyai visi terwujudnya sistem pendidikan sebagai pranata sosial yang kuat dan berwibawa untuk memberdayakan semua warga negara Indonesia berkembang menjadi manusia yang berkualitas sehingga mampu dan proaktif menjawab tantangan zaman yang selalu berubah.

Sedangkan misi pendidikan nasional adalah: (1) mengupayakan perluasan dan pemerataan kesempatan memperoleh pendidikan yang bermutu bagi seluruh rakyat Indonesia; (2) membantu dan memfasilitasi pengembangan potensi anak bangsa secara utuh sejak usia dini sampai akhir hayat dalam rangka mewujudkan masyarakat belajar; (3) meningkatkan kesiapan masukan dan kualitas proses pendidikan untuk mengoptimalkan pembentukan kepribadian yang bermoral; (4) meningkatkan keprofesionalan dan akuntabilitas lembaga pendidikan sebagai pusat pembudayaan ilmu pengetahuan, keterampilan, pengalaman, sikap, dan nilai berdasarkan standar nasional dan global; (5) memberdayakan peran serta masyarakat dalam penyelenggaraan pendidikan berdasarkan prinsip otonomi dalam konteks Negara Kesatuan RI.

Berdasarkan visi dan misi pendidikan tersebut maka pendidikan nasional termasuk perguruan tinggi (universitas) berfungsi mengembangkan kemampuan dan membentuk watak sebagai manusia yang bermartabat dalam rangka mencerdaskan kehidupan bangsa, bertujuan untuk mengebangkan potensi peserta didik agar menjadi manusia yang beriman dan bertakwa kepada Tuhan Yang Maha Esa, berakhlak mulia, sehat, berilmu, cakap, kreatif, mandiri, dan menjadi warga negara yang demokratis serta bertanggung jawab. Dan untuk mencapai visi dan misi pendidikan tinggi tersebut maka universitas perlu mengoptimalkan perannya dalam mencipta sumber daya manusia yang handal dan itu akan seiring dan sejalan dengan upaya meminimalisir gagal studi yang disebabkan kepribadian sulit dikalangan sebagian mahasiswa.

\section{PEMBAHASAN}

\section{Belajar di Universitas dan Kepribadian yang Sulit}

Belajar di universitas merupakan pilihan strategis untuk mencapai tujuan individual si mahasiswa melalui jalur formal. Kesenjangan persepsi dan pemahaman penyelenggara universitas, dosen dan mahasiswa mengenai makna belajar di perguruan tinggi dapat menyebabkan proses belajar tidak membuahkan hasil yang diinginkan dengan kata lain mengalami disfungsional. Belajar merupakan hak setiap orang dan untuk memutuskan belajar di Universitas mana merupakan hak setiap orang pula, sifatnya hak pribadi. Hak untuk memilih kuliah dan jurusan tertentu disamping meruapakan pilihan seseorang tentunya juga karena fasilitas, sarana dan prasarana belajar turut juga menjadi pertimbangan yang menetukann ditambah dengan pengakuan akan universitas yang menjadi sasaran untuk belajar juga diharapkan mencipta kualitas lulusan yang memadai. Dengan kata lain pengakuan kualitas lulusannya juga menjadi faktor kunci dari berhasil tidaknya universitas dan si mahasiswa itu sendiri tentunya perlu didukung oleh civitas academika yang berkualitas.

Untuk belajar di universitas sebenarnya memerlukan beberapa syarat dan dengan syarat itu sebenarnya juga memberi makna bahwa untuk belajar di universitas sebenarnya tidak semua orang dapat menjalaninya. Di samping syarat otak (penalaran) dan pemikiran, serta biaya (yang tidak murah) juga tentunya mampu tidak si mahasiswa untuk lulus di universitas tersebut perlu turut menjadi 
pertimbangan utama. Kalau dikejar lagi ada pertanyaan mendasar yaitu apakah lulusannya lulus dengan kualitas sangat baik, baik, buruk (jelek) atau sangat buruk. Untuk yang buruk dan sangat buruk bagiamana dampaknya bagi mahasiswa yang bersangkutan? Bagi masyarakat dan bagi bangsa dan negara? Terus bagaimana mahasiswa yang gagal dan putus ditengah jalan?

Mahasiswa yang telah mengalami proses belajar secara formal di universitas akan mempunyai wawasan, pengetahuan, keterampilan, kepribadian dan perilaku (karakter) tertentu sesuai dengan apa yang ingin dituju oleh lembaga pendidikan. Tujuan lembaga pendidikan pada umumnya dikaitkan dengan tujuan pendidikan nasional. Sekali lagi kegiatan belajar merupakan kegiatan individual, kegiatan yang sengaja dipilih secara sadar karena seseorang mempunyai tujuan individual tertentu. Belajar di perguruan tinggi merupakan suatu pilihan di antara berbagai alternatif strategik untuk mencapai tujuan individual. Kesadaran mengenai hal ini akan sangat menentukan sikap dan pandangan belajar serta menentukan bagaimana seseorang belajar diuniversitas. Mereka yang belajar di universitas dituntut tidak hanya mempunyai keterampilan teknis tetapi juga mempunyai daya dan kerangka pikir serta sikap mental dan kepribadian (carakter) tertentu sehingga mereka mempunyai wawasan yang luas serta mampu menyelesaikan masalah. Bila belajar diUniveritas tidak dapat mengubah wawasan sikap dan perilaku (karakter) akademik atau sosial maka tujuan pemebejaran tersebut akan tidak tercapai. Bila keadaan ini terjadi maka universitas akan kehilangan rohnya sebagai tempat belajar untuk mendidikan mahasiswa dan lebih parah lagi menjadi tempat hanya mencipta sarjana blangko kosong. Akibatnya, kontribusi universitas dalam mengubah keadaan masyarakat menjadi lebih baik dan maju akan menjadi kecil walaupun mungkin tujuan individual mahasiswa yang sempit dan jangka pendek tercapai.

Dalam keadaan seperti itulah, pendidikan perlu selalu diarahkan pada tujuan pendidikan tinggi itu sendiri. Tujuan universitas harus selalu diarahkan dan dipandu oleh tujuan pendidikan tinggi. Dan untuk mencapai tujuan tersebut perlu peran serta semua pihak termasuk seluruh civitas akademika. Untuk mencapai penguasaan ilmu, pengetahuan dan teknologi maka pendidikan sejatinya untuk itu perlu ada perubahan sikap dan perilaku (karakter). Bila tidak maka pendidikan di universitas akan kehilangan hakikat sesungguhnya. Untuk membentuk seorang mahasiswa yang menguasai ilmu pengetahuan dan teknologi perlu didukung sikap dan perilaku (karakter) yang mendukung. Untuk mendukung itu, maka universitas perlu menciptakan lulusan yang berkualitas. Untuk menciptakan lulusan yang berkualitas maka perlu diminimalisir mahasiswa yang memiliki kepribadian sulit. Sebab kegagalan mahasiswa bisa menjadi cermin dari kegagalan universitas. Dan kegagalan itu salah satunya disebabkan oleh kepribadian sulit yang menghinggapi mahasiswa.

\section{Sosok: Kepribadian yang Sulit}

Membahas kepribadian sulit di perguruan tinggi bukanlah perkara yang mudah. Parameter yang secara umum nampak dengan mudah adalah dari sikap perilaku mahasiswa di lingkungan kampus (universitas). Sikap dan perilaku yang mengarah pada kepribadian sulit seperti suka berbohong, suka tidak jujur, tidak mau kerja keras (sangat pemalas), tidak konsisten, sering tidak masuk atau bolos di kelas, tidak peduli dengan nilai (baik formal maupun subtantif), suka melawan siapa saja termasuk dosen, pimpinan jurusan, dekan dan universitas, memiliki sifat pembangkang (tipe teroris) dan lain sebagianya.

Dalam gambaran vulgar lainnya, di kampus atau universitas sering ditemui beberapa mahasiswa yang suka asal beda atau berpikiran harus selalu beda dengan siapa pun termasuk dosen. Mahasiswa seperti itu sebenarnya tidak salah bahkan seharusnya memang demikian kuliah di Universitas. Namun akan menjadi masalah besar bila ia berpikiran selalu beda dalam setiap hal walaupun salah, termasuk dengan dosen (unsur pimpinan dan staf). Bila sikap selalu berbeda walau salah dan tetap ngotot dengan kesalahan dan tidak mau mendengar orang lain maka itu akan mencederai roh pendidikan. Bila sikap dan perilaku asal beda dalam segala hal (walau salah sekalipun) 
diteruskan maka nilai-nilai keagungan dan kebenaran yang ditanamkan dosen (roh pendidikan) akan sulit menginternalisasi didiri mahasiswa. Dan bila itu dilanjutkan maka mahasiswa akan seperti blangko kosong dan hampa kuliah di Universitas. Mahasiswa demikian sering disebut tipe peperangan atau tipe teroris. Di kelas nampak, ketika dosennya berupaya dengan gaya apa pun, mahasiswa tersebut selalu menerima dengan bertolak belakang. Perilaku demikian menggambarkan jiwa atau pribadi yang berbeda dengan yang lainnya. Dalam kejiwaan orang yang tidak memiliki jiwa yang bukan pada umumnya bisa dikatakan kelainan jiwa. Mahasiswa yang demikian biasanya akan bahagia atau nyaman dengan situasi konflik, gaduh, dan tidak suka pada kondisi yang pada umumnya. Sikap atau jiwa yang demikian tentunya sangat berbeda dengan keinginan orang pada umumnya seperti rasa damai, tenang, aman, nyaman dan lancar. Dan mahasiswa yang bergaya demikian juga hanya segelintir orang.

Dalam perkembangan psikologi moden saat menekankan pentingnya emotional quotient dan soft skill untuk dapat mendukung kesuksesan seseorang. Dan hal tersebut bersebrangan dengan orang yang memiliki kepribadian sulit, orang yang merasa bahwa dirinya bisa hidup sendiri, bahwa kesuksesan yang dia peroleh sekarang akan terus melesat dan dia tidak akan butuh bantuan siapapun. Orang yang memiliki kepribadian sulit hadir dan ada di setiap lingkungan termasuk lingkungan universitas, membuat gerah dan terkadang meradang. Di lingkungan kampus terkadang dijumpai adanya perilaku seseorang mahasiswa yang jarang berbicara atau berpendapat, hanya sepatah dua patah kata dan kalaupun berbicara ia memosisikan orang lain goblok dan tidak berpikir serta tidak tahu. Dalam tugas kelompok yang ditugaskan dosen yang terjadi justru bukan diskusi untuk mencari kebenaran, justru pribadi yang sulit tersebut berlawanan dengan berbagai cara dan perilaku bahkan dengan tegas menolak sehingga tugas kelompok yang ditugaskan tidak dikerjakan seoptimal mungkin terkesan kacau, tidak jelas dan nilainya buruk.

Dalam menangani kepribadian yang sulit dosen perlu berupaya dan berpikir keras mencari alternatif pendekatan lain. Hal itu terjadi karena memang tidak mudah menangani orang yang mengalami kepribadian yang sulit apalagi kepribadian sulit seperti itu terkadang menular seperti virus dan juga tidak mau mendengar dari pihak luar dari siapapun, termasuk dosen. Dalam kehidupan kampus terdapat orang dengan kepribadian sulit perlu dipahami dan dimengerti serta disikapi dengan tepat sebab kalau tidak tepat akan mendatangkan masalah berikutnya termasuk berkaitan dengan kualitas yang dihasilkan dari proses pendidikan itu sendiri.

Orang yang berkepribadian sulit bukan sekedar berkaitan dengan cara memandang orang lain dan klaim kebenaran pribadi yang menyesatkan, bukan hanya sekedar kata-kata tetapi juga dapat juga berkaitan dengan sikap perilalu yang suka usil, gemar melakukan dan menuduhkan serta menimpakan kesalahan pada orang lain. Bila terjadi sesuatu maka ia langsung menuduh orang lain (suka menggonggong) yang salah, seolah-olah dia yang benar. Dalam hal ini, orang yang memiliki kepribadian sulit juga suka mengamati dan peduli orang lain serta berupaya mengenal lebih jauh tentang diri seseorang tetapi hanya sekedar untuk menyalahkan orang lain dan tidak berniat untuk memperbaiki. Yang mencolok dari orang yang memiliki kepribadian sulit ini adalah berupaya memanfaatkan situasi dan kondisi untuk semata-mata melakukan sesuatu yang berlawanan dari yang pada umumnya.

Berkaitan dengan sikap pemarah, orang yang memiliki kepribadian sulit suka marah-marah untuk sesuatu yang tidak jelas. Ia akan marah bila merasa kepentingan dan dirinya terancam bukan masalah benar atau tidaknya sikap dan perilaku yang ia lakukan. Sikap temperamental yang tidak berdasar alasan yang benar dan pada ummnya ini sering nampak pada orang yang memiliki kepribadian sulit. Perilaku yang suka marah-marah dalam upaya memperjuangkan sesuatu yang sebenarnya tidak benar, tidak umum dan tidak lazim adalah merupakan ciri utama orang yang mengalami kepribadian sulit. 
Sebagai contoh mahasiswa yang mengalami kepribadian sulit sangat kronis: ada mahasiswa yang namanya Irvan Syahputra yang kehadiran kuliahnya dalam 1 semester hanya 7 kali, itupun setiap hadir selalu terlambat dengan berbagai alasan yang terkadang tidak jujur/suka berbohong, kemudian UTS tidak ikut dan tidak mengerjakan quis atau tugas. Dia datang ke dosen dan marah-marah dan menjelaskan tanpa ada bukti data yang memadai bahwa ia pantas lulus, karena rajin, dan selalu mengerjakan tugas tepat waktu. Dosen sudah menjelaskan syarat kelulusan kehadiran minimal 9 kali dari 13 pertemuan (toleransi 4 kali absen) bila tidak memenuhi syarat tersebut maka nilai mahasiswa langsung E oleh sistem apalagi mahasiswa tidak datangya tidak dapat menunjukan surat ijinnya. Alasan dosen tersebut sudah didukung dengan data yang ada namun si mahasiswa pergi dengan marah-marah terkesan tidak mau menerima penjelasan dosen bahkan dia justru lapor ke sekretaris jurusan, jurusan dan bahkan sampai ke dekan.

Mahasiswa tipe kepribadian yang sangat sulit tersebut dapat mengalami keadaan yang serba sulit dan terkadang menyulitkan banyak pihak. Bila mahasiswa yang mengalami hal seperti ini maka adalah tugas institusi universitas yang perlu lebih ekstra. Bila penanganan tidak tepat maka akan mendatangkan masalah lanjutan yang tidak mudah. Yang jadi pertanyaannya mendasar bagaimana bila mahasiswa yang mengalami kepribadian sulit kronis ini bila selalu lolos?apakah ia nanti menjadi sarjana blangko kosong/pepesan kosong? Otaknya sarjana tetapi sikap dan perilaku serta tingkat ilmu pengetahuan yang tidak mendukung? Apakah peranan dan tanggung jawab universitas terlepas ketika lulusan sarjana blangko kosong ini ke masyarakat? Bagaimana kalau nanti jika lolos menjadi anggota masyarakat yang bermasalah? Seabreg pertanyaan tersebut perlu dipikirkan dan dicarikan solusi sejak dini, untuk dapat dikatakan pendidikan sebagai upaya mendidik anak manusia menjadi manusia yang berdaya saing dan memiliki kepribadian yang unggul, akhlaq mulia serta bertaqwa pada Tuhan Yang Maha Esa.

\section{Tipe Kepribadian}

Manusia memiliki beragam tipe kepribadian tentunya yang dimaksud manusia juga termasuk mahasiswa yang sedang menimba ilmu di universitas. Pengenalan tipe-tipe kepribadian ini sangat penting untuk dapat memahami bahwa ditengah-tengah kehidupan maninusia ini terdapat orang-orang dengan tipe kepribadian tertentu. Setelah mengenal tipe kepribadian tersebut diharapkan nantinya menjadi anggota masyarakat yang baik terutama dalam menjalin hubungan dengan sesama umat manusia.

Seorang mahasiswa akan menjalin hubungan dengan siapa pun, baik itu orang yang baru ataupun yang sudah lama dikenal, tentu ada yang dengan mudah tetapi tentunya terkadang akan menghadapi tingkat kesulitan yang berbeda-beda yang berkaitan dengan tipe kepribadian yang berbeda-beda pula. Dalam kehidupan kampus di universitas terkadang ada mahasiswa dengan mudah bergaul dengan mahasiswa lainnya tetapi terkadang ada sebagian mahasiswa lain menemui kendala dan benturan sehingga sulit untuk menghadapinya. Untuk itu perlu dimengerti dan dipahami tipe mahasiswa yang mengalami kepribadian sulit.

Tipe Pertama, tipe kepribadian yang suka memaksa. Tipe mahasiswa yang suka memaksa ini terkadang bukan untuk kebenaran umum tetapi demi untuk mengejar ambisi pribadi atau kekuasaan pribadi. Mahasiswa jenis ini menginginkan menjadi pemenang sehingga mahasiswa lain atau orang lain perlu dikalahkan. Mahasiswa seperti ini juga ingin mendominasi dengan memaksa pihak lain untuk ikut atau tunduk. Teman mahasiswa lain dipandang sebagai alat untuk menuju kepuncak kekuasaannya. Bila yang diinginkan belum tercapai maka dia berusaha mendapatkan dengan memaksa. Dan selalu meng-intimidasi siapa saja termasuk teman-temannya. Kehidupan mahasiswa tipe pemaksa bukan dipandang sebagai jalan tengah atau kompromi tetapi berdasarkan menang kalah, kalau saya menjadi pemenang maka yang lain harus kalah dan pihak lain perlu dikalahkan. Dalam pandangan seperti itu maka didalamnya sering terjadi pengancaman (intimidasi) terhadap mahasiswa lain. 
Mahasiswa tipe seperti ini biasanya memiliki ego yang sangat tinggi. Dalam pandangan umum, mahasiswa tipe pemaksa terlihat sangat egois. Sifat egois tersebut nampak dalam sikap dan perbuatan yang mementingkan pandangan dirinya sendiri dan merasa benar sendiri terkadang susah menyesuaikan dengan mahasiswa lain. Dan kalau dicermati sebenarnya justru disitu juga yang menjadi kunci dalam memahami, mengerti, dan mencari solusi terhadap tipe kepribadian sulit tipe ini. Mahasiswa perlu mengutarakan apa yang menjadi keinginannya secara lengkap, didengarkan dan dicarikan solusi mahasiswa lain atau pihak lain perlu banyak mendengar. Sebab bila mahasiswa atau pihak lain yang banyak bicara maka justru memunculkan dan mengedepankan sikap egoisme. Bagaimanapun menangani tipe pemaksa ini tidak mudah dan perlu usaha yang hati-hati kalau tidak mahasiswa yang memiliki tipe ini semakin keras dan hidup pada dunianya sendiri.

Tipe kedua, mahasiswa tipe kedua ini hampir sama dengan yang pertama bedanya adalah mahasiswa memiliki ego yang tinggi namun dalam menerapkannya dengan cara yang halus atau ddiam-diam. Upaya untuk menggapai apa yang diinginkan yang sebenarnya sangat egois tetapi caranya menyerupai agen yang sangat rahasia. Jadi tipe kedua ini sebenarnya mirip dengan yang pertama, segaris hanya saja dalam mengungkapkan ego nya dapat dikatakan berlawanan. Hal yang menonjol dari mahasiswa tipe kepribadiansulit tipe ini adalah mainnya diam-diam, tidak kentara dan halus. Perilaku seperti ini kalau sangat berlebihan akan menjadi masalah bagi yang lain. Banyak hal tugas, ataupun pekerjaan akan minim masukan dari yang lain tahu-tahu sudah diputuskan. Pengambilan keputusan model seperti ini sering meenimbulkan peta konfli dan konflik. Di lingkungan organisasi kampus mahasiswa tipe ini cenderung galak untuk mencapai tujuan tertentu tetapi dia tidak memaksakan pihak lain sebagai peembeda dari tipe yang pertama. Untuk mengantisipasi mahasiswa tipe ini maka perlu dikembangkan pemikiran/sikap positif yang dikedepankan sebab bila sikap negatif yang diutamakan maka akan mengganggu wilayah kekuasaan mahasiswa tipe ini.Yang menarik bila tipe pertama dan kedua bertemu maka tipe pertama bersikap cerewet untuk memaksakan egonya dan itu berbanding terbalik dengan tipe kedua yang tampil lebih banyak diam, lebih sering menahan informasi untuk memaksimalkan perasaan bahwa mereka penting.

Oleh karena itu, cara berhubungan yang harmonis dengan seorang tipe kedua adalah dengan menarik ia agar terlibat keluar, diberi cukup kepercayaan sehingga mereka mau berbaur dan nampak sikap yang sesungguhnya meminimalisir sikap yang penuh dengan rahasia. Pendekatan yang baik adalah perlu banyak bertanya agar kerahasiaan sikap dan agenda yang tersembunyi dapat diungkapkan, tetapi tetap harus menunjukan sikap dan kesan positif. Sebab kalau tidak nampak kesan positifnya maka tipe kedua justru akan menolak dengan cara yang berlawanan dengan maksud dari pendekatan itu sendiri. Dengan kata lain, untuk menangani mahasiswa tipe kedua ini tidaklah mudah dan tanpa rintangan namun yang pasti bisa diterapkan. Yang dapat menarik dan unik dari mahasiswa dengan tipe kepribadian yang serba rahasia ini adalah mahasiswa sulit tipe kepribadian sulit kedua jarang jarang mencapai puncak (leader) di organisasi kampus. Adalah fakta mahasiswa tipe kepribadian sulit kedua tidak punya ambisi atau keinginan untuk mencapai puncak pimpinan suatu organisasi, dan yang terasa lebih senang main dibelakang layar. Dan hebatnya tipe kedua lebih cocok menjadi pemimpin atau menjalankan kekuasaan jauh dari sorotan publik atau pusat perhatian orang lain. Tipe ini mungkin dikenal luas sebagai orang yang dibalik layar. Untuk memberi jalan pada tipe orang yang serba rahasia ini maka upaya dan dukungan perlu dilakukan agar dapat membantu menjadiksnnys sebagai pemain dibalik layar yang hebat dan menentukan dan hal tersebut perlu menjadi diprioritaskan untuk tipe mahasiswa yang penuh rahasia.

Tipe ketiga, mahasiswa tipe rajin dan menyenangkan. Mahasiswa tipe ketiga ini sepertinya tampak menyenangkan dan patuh. Untuk menghadapi tipe ketiga ini, setiap orang yang berhubungan dengannya juga perlu trik (langkah) yang tepat. Biasanya tipe ketiga berkaitan dengan mahasiswa baru yang ada di suatu organisasi kampus dan juga mahasiswa baru. Mahasiswa tipe ini berusaha dan terkadang tidak sabar untuk bisa dengan cepat menyerap budaya organisasi/sekolah/kampus. Dalam permulaan mahasiswa menginjak kuliah dikampus biasanya mempunyai rasa kagum kepada orang lain tanpa perlu menyembunyikannya, pokoknya begitu menyenangkan. Tipe menyanangkan ini akan 
semakinsenang dan tersanjung bila mendapat pujian, tetapi tentunya orang atau mahasiswa lain belum tentu memberikan pujian tersebut sehingga terkadang tipe ketiga ini mencarinya sendiri dengan cara sendiri. Dalam keadaan terakhir itulah yang terkadang kearah yang negatif karena kesenangan yang dapat diciptakan ternyata kesenangan tanpa arah bahkan bisa jadi kesenangan dengan arah yang negatif.

Untuk memahami tipe kepribadian ketiga, maka perlu dipahami dan dimerngerti dan dari perspektif pertemanan, yang paling baik adalah mengakui kelebihan dan kekurangan tipe tersebut. Tipe mahasiswa yang menyenangkan memiliki sisi positif dan negatifnya perlu dipahami secara tepat. Dalam organisasi pada umumnya, tipe menyenangkan memiliki memiliki idealisme yang umum karena mereka memiliki banyak energi, cerdas, semangat, dan mau bekerjasama sehingga menciptakan sinergi yang baik dalam organisasi. Tetapi juga perlu diingat sikap menyenangkan seperti itu bukan berarti si mahasiswa tipe ketiga tersebut tidak memiliki sikap yang berkecenderungan negatif, sikap dan perilaku yang negatif dari sikap menyenangkan tetap akan terbuka terutama bila keadaan dan kondisi tidak mendukung kearah yang positif. Pada prinsipnya setiap mahasiswa dapat memiliki kepribadian yang menyenangkan tetapi jika tipe ketiga diperlakukan dengan buruk, maka mereka dapat bertolak menjadi mahasiswa yang memiliki kepribadian yang sulit dan gagal dalam studi atau belajar di universitas. Sikap dan perilaku peralihan dari sikap penyenang, periang dan cerdas akan berubah, yang tadinya percaya diri dan bergairah akan berubah menjadi pribadi yang terluka, tertekan, dan hampir merasa menjadi orang yang tak berguna. Dalam kondisi terakhir inilah tipe kepribadian sulit dapat terlahir. Oleh karena itu, sebenarnya semua tergantung dari bagaimana bisa memahami mereka dengan menggunakan pemahaman dan cara yang tepat agar si mahasiswa justru tidak menjadi mahasiswa yang mengalami kepribadian yang sulit. Bila kepribadian sulit tipe ini tidak diantisipasi maka dapat beresiko pada kegagalan kuliah di universitas yang tentunya sangat merugikan semua pihak terlebih-lebih mahasiswa itu sendiri karena kegagalan kuliah didepan mata.

Tipe keempat, yang termasuk tipe ini adalah mahasiswa yang selalu tampil tertekan, ditekan, atau disingkirkan.Walaupun terkadang tidak jelas siapa yang menekan atau yang disingkirkan namun tipe mahasiswa ini yang nampak kemuka adalah tampil sebagai orang yang tertekan/menekan atau merasa disingkirkan. Sebenarnya mahasiswa tipe keempat banyak dijumpai dilingkungan kampus termasuk di Organisasi yang ada dikampus. Jumlah mereka sangat mendominasi sehingga perlu penanganan secara khusus agar dapat menjalin hubungan yang harmonis. Perlu waktu yang cukup lama untuk menghadapi dan membantu mereka agar menjadi pribadi yang pada umumnya. Tipe orang yang selalu tampil tertekan, ditekan, atau disingkirkan di suatu organisasi kampus biasanya mereka tidak puas dengan kondisi yang ada. Dan sekali lagi sebenarnya ketidakpusan dapat dengan mudah ditemukan dilingkungan kampus atau universitas atas situasi dan kondisi yang ada. Hanya saja bila sampai mengarah pada kepribadian yang sulit itu akan menjadi masalah yang serius bagi semua pihak. Sebenarnya tipe keempat ini mempunyai kemampuan dan keahlian yang sangat berharga untuk memperkenalkan budaya organisasi kampus. Oleh karena itu, perlu memakmalkanl mereka harus mendapatkan sebuah energi baru yang telah hilang dan menjadikannya mahasiswa berguna. Untuk menghadapi mahasiswa tipe ini maka perlu dihindari sikap sering mengritik, menyalahkan dan menghukum. Cara-cara demikian sebenarnya tidak dapat diperuntukan bagi mahasiswa tipe keempat. Bila cara demikian dilakukan bisa jadi justru akan melahirkan tipe mahasiswa baru dengan kepribadian yang sangat sulit.

\section{PENUTUP}

Belajar di universitas merupakan pilihan individu si mahasiswa secara mandiri. Pilihan itu ditentukan oleh banyak faktor dari masalah fasilitas pendidikan, sarana, prasarana dan kualitas dosen juga pengakuan dari nama universitas itu sendiri. Dengan memilihnya belajar di Universitas maka harapan mahasiswa adalah agar dapat lulus dengan kualitas yang memadai. Untuk mendukung hal tersebut maka perlu diciptakan situasi dan kondisi sehingga tujuan pembelajaran yang sekaligus 
merupakan tujuan dari universitas dan pendidikan tinggi tercapai. Kehidupan mahasiswa di universitas mengalami banyak dinamika. Salah satu kendala krusial dan mendasar yang dapat mengancam keberhasilan belajar di universitas adalah masalah kepribadian sulit. Banyak mahasiswa gagal belajar di universitas karena mengalami kepribadian yang sulit tersebut. Oleh karena itu, penanganan kepribadian sulit dikalangan mahasiswa perlu segera dilakukan. Upaya mengatasi kepribadian sulit tersebut perlu dilakukan dengan mengedepankan dan berdasarkan tujuan pendidikan yang tepat. Hal itu perlu dipikirkan semua pihak terutama civitas akademika di univeritas untuk menciptakan mahasiswa yang disamping memiliki dan menguasai ilmu pengetahuan dan teknologi serta memiliki berkepribadian (berkarakter) yang baik.

\section{DAFTAR PUSTAKA}

Davis, I. K. (1971). The management of learning. London: McGraw-Hill.

Gartside, L. (1989). English for business studies (3rd ed.). Jakarta: Binarupa Aksara.

Hall, W. C., \& Cannon, R. (1975). University Teaching. Adelaide: ACUE, The University of Adelaide.

International Extension College. (1979). Writing for Distance Education. Cambridge, England: IEC.

Moeliono, A. M. (1989). Kembara bahasa: Kumpulan karangan tersebar. Jakarta: Gramedia.

Neusner, J. (1984). How to grade your professors and other unexpected advice. Boston: Beacon Press.

Nurhadi, M. A. (n.d.). Proses belajar-mengajar. Makalah disampaikan pada Seminar Modus BelajarMengajar. Fakultas Ekonomi UII Kaliurang.

Republik Indonesia. (2003). Undang-Undang No. 20 Tahun 2003 tentang Sistem Pendidikan Nasional. Jakarta: Lembar Negara Republik Indonesia Tahun 2003 Nomor 78.

Republik Indonesia. (1945). Undang-Undang Dasar 1945.

Sterling, R. S. (1987). Accounting research, education and practices. Dalam R. G. Schroeder, et al., Accounting Theory: Text and Reading. New York: John Wiley and Sons.

Suwardjono. (1991). Belajar di perguruan tinggi. Jurnal Akuntansi \& Manajemen, edisi Maret 1991. 